Este estudo foi escrito com base num texto mais abrangente sobre a crítica teatral de Machado, a ser publicado no segundo semestre deste ano, como introdução ao livro Machado de Assis: do Teatro (Textos Críticos e Escritos Diversos), que organizei para a Editora Perspectiva.

\section{Machado de Assis} e os estilos de

interpretação teatral de seu tempo

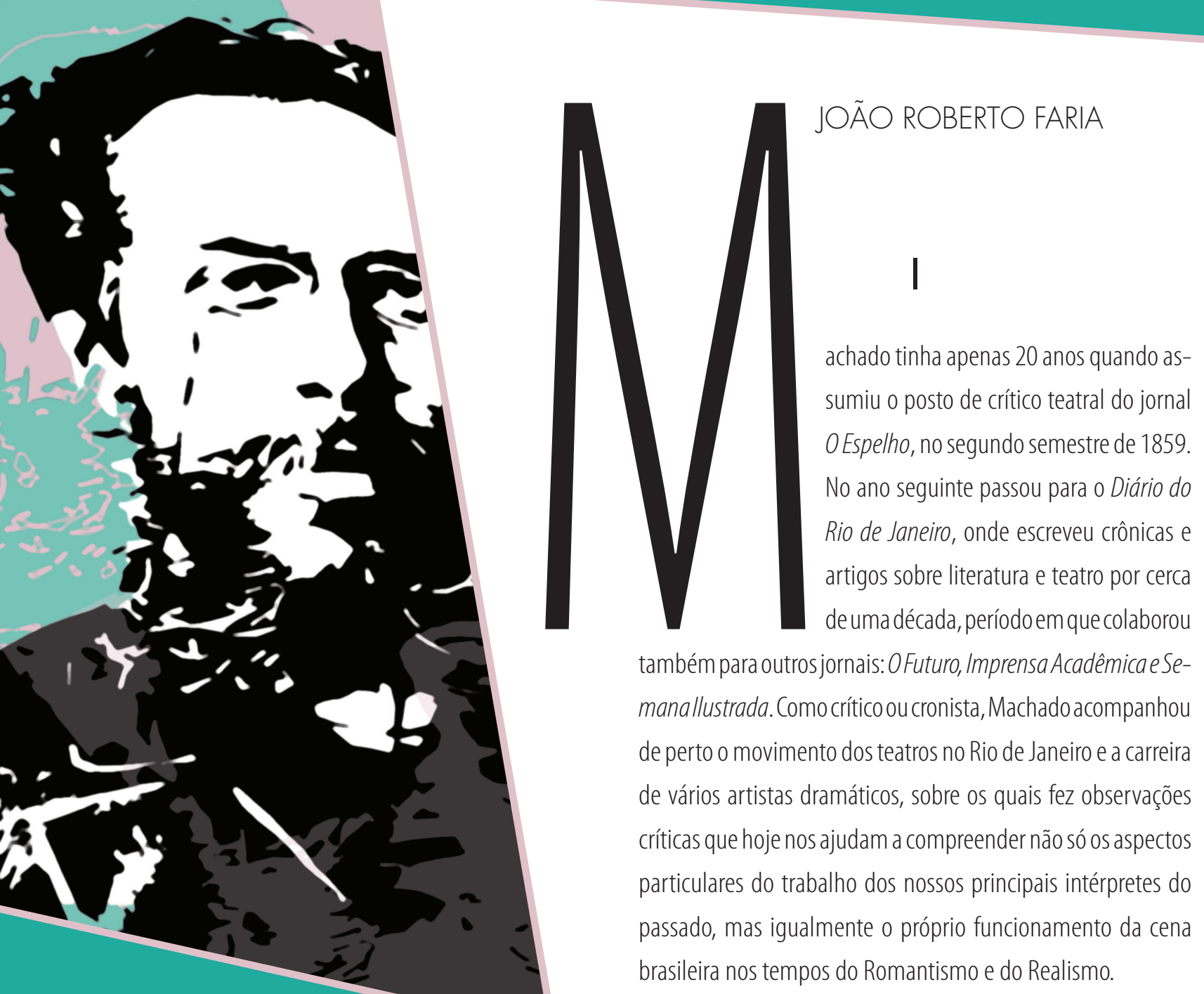

JOÃO ROBERTO FARIA

é professor de Literatura Brasileira da FFLCH-USP e autor de, entre outros, Idéias Teatrais: o Século XXI no Brasil (Perspectiva/ Fapesp). 
O grande nome do teatro brasileiro de então era João Caetano, ator consagrado por uma carreira iniciada em 1827, aos 19 anos de idade, e marcada por interpretações que impressionaram os seus contemporâneos ao longo de mais de trinta anos, em tragédias neoclássicas, dramas românticos e melodramas. Autodidata, João Caetano estudou o ofício em manuais escritos por homens de teatro de formação clássica, como François Riccoboni e Aristippe. Do primeiro, leu L'Art du Théâtre, de 1750, e do segundo, Théorie de l'Art du Comédien ou Manuel Théâtral, de 1826. A primeira obra, em tradução espanhola, serviu-lhe de base para elaborar um livreto que intitulou Reflexões Dramáticas, em 1837, e ambas -além de outras apenas circunstanciais-para escrever uma obra mais ambiciosa, Lições Dramáticas, em 1862.

Em seus dois livros João Caetano aceita em bloco as idéias teóricas dos autores franceses e defende os princípios clássicos da interpretação, aqueles que eram ensinados no Conservatoire de Paris e vistos no palco da Comédie Française. Em síntese, pode-se dizer que o ator formado nessa escola tinha como postulado estético "a idealização, o enobrecimento da realidade" e a seguinte orientação:

"Privilegiava-se o espírito sobre o corpo, o estilo elevado sobre o coloquial, o verso sobre a prosa, a expressão oral sobre a mímica, a paráfrase sobre a locução direta, as classes superiores sobre as inferiores. Representar era dizer bem, inflexionar com exatidão, valorizar a sonoridade e o ritmo da frase, sugerir um universo refinado onde a própria paixão, sem perder a força, se transformasse em música e poesia"1.

Dentro desse quadro, João Caetano Decio de Almeida Prado, João Caetano, São Paulo, Perspectiva/Edusp, 1972, p. 112.

2 Idem, João Caetano, op. cit., 1972; e João Caetano e a Arte do Ator, São Paulo, Atica, 1984. São dois livros fundamentais para se conhecer a trajetória artística de João Caetano e seu papel na história do teatro brasileiro. também o que considera equívocos, istoé, os momentos em que não conseguiu manter em cena uma interpretação equilibrada, natural, vigiada pela razão e inteligência. Assim, conta que certa vez quase estrangulou a pobre atriz Estela Sezefreda - com quem viria a se casar - numa cena de ciúmes, provocando a interrupção do espetáculo pelo público assustado e pelos companheiros de palco. Em outra ocasião, ficou no camarim entre um ato e outro, afogado em soluços, de tanta emoção que lhe provocou o papel principal da tragédia Antônio José ou o Poeta e a Inquisição, de Gonçalves de Magalhães.

João Caetano lembra criticamente esses momentos - porque não conseguira separar os seus sentimentos pessoais dos sentimentos dos personagens, como apregoava a poética teatral clássica, amparada no famoso "paradoxo do comediante" de Diderot. Mas foi graças a eles, a sua intempestividade no palco, aos rompantes imprevistos e por vezes geniais que atingiu a glória, como bem demonstrou Decio de Almeida Prado nos dois livros que lhe dedi$\mathrm{cou}^{2}$. A seu ver, João Caetano queria que o público o admirasse como ator trágico. Daí o grande número de tragédias neoclássicas em seu repertório, principalmente nos anos de 1830 e 1840 . Porém, pouco a pouco os melodramas se mostraram mais rentáveis e se tornaram hegemônicos em relação aos outros gêneros dramáticos. Como pediam um tipo de interpretação diferente, João Caetano especializou-se em papéis que exigiram todo o tipo de virtuosismo e nenhum limite técnico. Nesse sentido, ainda segundo Decio de Almeida Prado, a escola do melodrama teve importância decisiva na formação do ator, e explica

"[...] as suas qualidades e defeitos, a tendência para o exagero, a busca do patético a qualquer custo. Era uma representação extrovertida, solta, explicitada, de intenções marcadas, de gestos largos, de efusões emocionais, de arroubos oratórios, sem preocupações com a elegância ou com a pureza estilística, romântica na medida em que a espontaneidade e a autenticidade 
do sentimento contavam mais que os requintes da técnica"3.

Em outras palavras, João Caetano era um ator sensível, emocional, explosivo, mais próximo dos atores românticos do que dos clássicos que tinha por mestres. Ou seja, se o seu modelo era o grande ator trágico Talma, que tanto admirava, no palco lembrava mais, até pela coincidência de repertório, o maior de todos os intérpretes de melodramas, Frédérick Lemaître.

Pode-se dizer que entre os extremos da interpretação clássica e da melodramática situa-se a interpretação romântica, ditada evidentemente pelo coração, pela sensibilidade e pela idéia de que o ator deve vivenciar as emoções do personagem. $\mathrm{O}$ bom ator romântico é o que evita os exageros da interpretação melodramática, mantendo porém a intensidade do papel que desempenha. $\mathrm{E}$ muitas vezes isso se conseguia com a ajuda dos textos dramáticos concebidos com profunda preocupação literária, algo que não existe no melodrama. As dificuldades para se perceber as diferenças entre esse gênero popular e o drama romântico, no século XIX, foram muitas, porque, tanto na França quanto no Brasil, eram os mesmos artistas que os representavam. Lá, Marie Dorval, Bocage e Frédérick Lemaître; aqui, João Caetano, Estela Sezefreda, Ludovina Soares da Costa, Germano Francisco de Oliveira ou Florindo Joaquim da Silva, entre outros.

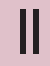

Vários espetáculos protagonizados por João Caetano e pelos artistas da sua companhia dramática foram vistos por Machado, que registrou suas impressões acerca não só do trabalho do intérprete como também do papel do empresário. De um modo geral, Machado respeitava o talento de João Caetano, chegando mesmo a elogiar o seu desempenho como ator trágico na tragédia Cinna, de Corneille, e como ator melodramático no melodrama Simão ou o Velho Cabo de Esquadra, de Dumanoir eAdolphe
Dennery. Se, na primeira, “o seu gesto foi nobre e adequado, a sua declamação justa e grave"4, na segunda "esteve eminente nos últimos quatro atos", principalmente no segundo: "Aqui o contraste é de um belo efeito. A alegria e a chufa do campo de batalha tornaram-se em abatimento e tristeza. O mudo é perfeito; há expressões, emoções bem desenhadas; e a frase acional é precisa, simples e eloqüente" 5 .

Os elogios mostram a capacidade de João Caetano em gêneros diametralmente opostos, um alicerçado na palavra, na arte de dizer os versos, outro baseado na ação física, na gestualidade exuberante, comoexige o enredo centrado na história de Simão, um infeliz que fica mudo ao presenciar um crime e que não pode denunciar o criminoso por não saber escrever.

Quando João Caetano morreu, em 1863 , Machado reiterou os elogios ao desempenho de Augusto, da tragédia Cinna, afirmando que o ator, "perfeitamente convencido da natureza do personagem que tinha a representar e da importância do poema de Corneille, deu a ambos, no que lhe tocava, o cunho da verdade e da elevação, sem o qual ficava desrespeitada a obra do divino poeta" ( $C T$, p. 189). Ninguém o igualou na tragédia e no drama, afirma ainda Machado, que via nele uma intuição poderosa, que compensava a falta de estudos regulares sobre a arte do intérprete. "Dotado de talento superior e admiráveis dotes", arremata, “destacava-se ele soberanamente do grupo dos demais talentos. Tinha por si, nas ocasiões supremas, uma inspiração que em vão se procurará nos talentos de ordem inferior" (CT, p. 187).

As qualidades apontadas pelo articulista - a intuição e a inspiração - aproximam o ator do Romantismo. Machado elogiou uma interpretação de João Caetano como ator trágico, mas no balanço final destacou também os defeitos do ator-empresário que fez concessões à platéia que preferia os melodramas às peças de valor literário. Vítima de seu próprio sucesso e - por que não? - da sua vaidade, o ator deixou-se levar pelos aplausos fáceis e pela bilheteria, merecendo por isso duras reprimendas de Machado:

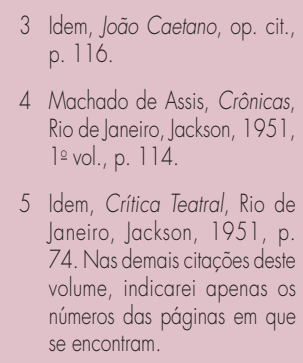


"Qualquer que fosse a latitude das suas eminentes faculdades, não era fácil a João Caetano resistir à atmosfera viciada que respira o teatro brasileiro.

Contribuíram no seu tanto para esse deplorável resultado as vitórias prematuras do palco. As platéias soberanas, na distribuição dos sufrágios, não conhecem nem se empenham pela observância estrita do catecismo da arte. O artista as comovia e exaltava, e o aplauso fervente, ruidoso, espontâneo acolhia os rasgos de talento confiante de si.

De sucesso em sucesso, verde de anos, convencido da própria capacidade, o artista deixou-se levar por essa onda, desassombrado de êmulos, embebido no presente e descuidoso do porvir. Tal foi o seu erro ou a sua fatalidade. Estava só na altura em que Deus o pusera, via correr os seus dias marcados por ovações, e, sem contradita nem competência, não puderam as suas faculdades adquiriro sumo grau da necessária perfeição" (CT, pp. 187-8).

Vale acrescentar que essa é uma avaliação de muitos outros intelectuais da época, que, em diversas ocasiões, censuraram João Caetano por entender que ele, ao longo da carreira, preocupou-se muito com a glória pessoal e pouco com o teatro brasileiro. Machado, nos folhetins de 1859, já havia feito esse tipo de censura e apontado também que o ator estacionara num patamar artístico que, embora alto, não se abria às novas formas de interpretação que chegavam ao país com o realismo teatral. Assim, não lhe perdoava o repertório anacrônico, a falta de iniciativa para se atualizar como artista, as descaídas no exagero interpretativo, o que significava manter o seu público distanciado das novas tendências teatrais. A reapresentação de A Nova Castro, tragédia neoclássica de João Batista Gomes Júnior, que João Caetano vinha oferecendo ao público desde 1839, motivou essas palavras:

“Aprecio o Sr. João Caetano, conheço a sua posição brilhante na galeria dramática de nossa terra. Artista dotado de um raro talento escreveu muitas das mais belas páginas da arte. Havia nele vigorosa iniciativa a esperar. Desejo, como desejaram os que protestaram contra a velha religião da arte, que debaixo de sua mão poderosa a platéia de seu teatro se eduque e tome uma outra face, uma nova direção; ela seconverteria decerto às suas idéias e nãooscilaria entre as composições-múmias que desfilam simultâneas em procissão pelo seu tablado" (CT, p. 58).

A mesma censura encontra-se no folhetim em que comenta a reencenação de $O$ Sineiro de São Paulo, de Joseph Bouchardy. Arrancado "do pó do arquivo", velho "na forma e no fundo; pautado sobre os preceitos de uma escola decaída, limpo totalmente de mérito literário", esse melodrama era um "regalo de antepassados infantes que mediam o mérito dramático de uma peça pelo número dos abalos nervosos". Nesse texto Machado vai ainda mais longe em suas críticas: vê defeitos no trabalho e no caráter do ator. Coloca-se como alguém que tem ilusões, que acredita que "a fortuna pública não está só em um farto erário, mas também na acumulação e circulação de uma riqueza moral". Palavras duras, acrescidas de outras, nas quais afirma ver a arte não como uma "carreira pública", mas como "uma aspiração nobre, uma iniciativa civilizadora e um culto nacional” (CT, pp. 98-9).

Como as "composições-múmias" continuaram a subir à cena do Teatro São Pedro de Alcântara, Machado, que não se conformava em ver o maior teatro do Rio de Janeiro nas mãos de um ator que não abdicava de suas velhas concepções teatrais, não se cansou de criticar os dramalhões e os artistas que, imitando João Caetano, traziam não as suas qualidades, mas os seus defeitos para o palco. O exagero da interpretação melodramática, por exemplo, parece ter seduzido o ator Barbosa, censurado em vários folhetins por Machado, em termos às vezes bastante saborosos, como nesta passagem: “O Sr. Barbosa continua nas suas exagerações; toma gestos e inflexões de voz hiperbólicos, alonga as palavras, carregando sobre elas, tortura a língua, a arte, e a paciência dos pensadores que lá vão" (CT, p. 74). Em outro folhetim, afirma que o ator não esteve à altura do 
papel que devia desempenhar: “[...] fez de uma criação grosseira uma entidade banal. Locução laboriosa, arrastada, com os $r r$ de carrinho, e as frases pronunciadas gota a gota; gesto grotesco, contorções de corpo e de fisionomia, eis pouco mais ou menos o belchior dos Dez Contos de Papelote" (CT, pp. 135-6). O uso inadequado da voz, com impostação exagerada, não era um defeito apenas do ator Barbosa. Também Florindo Joaquim da Silva, ator de prestígio na época, foi censurado em sua interpretação do conde Plonzastee, da peça As Mães Arrependidas, de F. Mallefille: "Tinha uma voz modulada; nada de inflexão natural, nada da maneira própria de falar. Forcejava por pronunciar letra por letra, mas traía ainda assim as regras da arte; fazendo parecer uma galeria de palavras sem expressão, como corpos sem alma" (CT, p. 130).

Machado criticou outros artistas da companhia dramática de João Caetano que, a seu ver, extrapolaram os limites da boa interpretação, caindo em exageros melodramáticos ou demonstrando pouco estudo dos papéis. Mas reservou elogios para Martinho Corrêa Vasques, reconhecendo-lhe o talento cômico, e para Ludovina Soares da Costa, atriz portuguesa que chegara ao Brasil em 1829, aos 27 anos, já com fama de grande intérprete de tragédias. Para Machado ela era a "trágica eminente, na majestade do porte, da voz e do gesto, figura talhada por um quinto ato de Corneille, trágica - pelo gênio e pela arte, com as virtudes da escola e poucos dos seus vícios" (CT, pp. 132-3).

\section{III}

É possível entender melhor as restrições aos artistas do São Pedro deAlcântara se nos lembrarmos que Machado, já nos primeiros textos do jornal $O$ Espelho, define sua posição contrária ao romantismo teatral, não só em termos de dramaturgia como também de interpretação. Não gostava dos melodramas e dos "vícios da velha escola", porque aprendera a admirar os artistas do Teatro Ginásio Dramático, que desde 1855 ofereciam à platéia do Rio de Janeiro um repertório de peças francesas modernas, de autores como Alexandre Dumas Filho e Émile Augier. Eram as comédias realistas, também chamadas de "dramas de casaca", que traziam para a cena os costumes e os valores da burguesia, vistos positivamente nos enredos construídos com finalidade edificante. Tais peças exigiam um estilo de interpretação completamente diferente do que se via na companhia dramática de João Caetano. O jogo de fisionomia, a voz, a gestualidade, tudo pedia a maior naturalidade possível, porque o importante era "fazer que oito ou dez personagens criados pelo nosso pensamento vivam no teatro como se fossem criaturas reais, habitando uma das casas do Rio de Janeiro" ". São palavras de José de Alencar, o primeiro dramaturgo brasileiro a escrever peças com base no modelo de Alexandre Dumas Filho. Em 1857, depois de saborear o sucesso de $O$ Demônio Familiar, no Ginásio Dramático, explicou numa carta a Francisco Otaviano, que o Diário do Rio de Janeiro publicou em 14 de novembro de 1857 , como e por que escreveu sua "alta comédia”. As palavras acima transcritas fazem parte da explicação que deu acerca do “jogo de cena” realista e das diferenças que existem em relação à encenação romântica.

O que salta aos olhos é que um único pressuposto teórico parece fundamentar o estilo de interpretação realista: a naturalidade. Alencar observa que no espetáculo romântico os artistas "representam" e tendem à dramatização; as cenas são construídas com lances dramáticos cediços, que se arranjam com palavras enfáticas e entradas imprevistas; por fim, o ator romântico procura chocar os nervos do espectador com gritos e gestualidade exasperada. Em contrapartida, o ator realista "vive" o papel que lhe é dado e tende à naturalidade; as cenas não fogem do que é natural e os artistas movem-se e falam como se fossem indivíduos tomados ao acaso em qualquer sala; o ator realista busca atingir o espírito ou o coração do espectador e não teme o silêncio ou o movimento vagaroso em cena.

Alencar, sintonizado com a renovação teatral levada a cabo pelo Ginásio Dramáti-
6 José de Alencar, "A Comédia Brasileira" in O Demônio Familiar, Campinas, Editora da Unicamp, 2003, p. 35. 
co, propõe um caminho novo para a dramaturgia e para a cena, finalizando o seu texto com um recado direto a João Caetano: “O tempo das caretas e das exagerações passou. Inês de Castro, que já foi uma grande tragédia, hoje é para os homens de gosto uma farsa ridícula" .

Machado, que entre os 17 e os 20 anos de idade acompanhou a rivalidade entre o São Pedro de Alcântara e o Ginásio Dramático, aliou-se a Alencar, dez anos mais velho, e aos outros jovens da sua geração que atuavam no jornalismo. Seu apoio ao Ginásio é explícito já no primeiro folhetim escrito para $O$ Espelho, em 11 de setembro de 1859. Entre a "escola romântica" e a "escola realista", diz "pertencer" à segunda, que é "mais sensata, mais natural, e de mais iniciativa moralizadora e civilizadora" (CT, p. 30). Nesse folhetim os elogios aos artistas do Ginásio são genéricos, mas duas semanas depois, ao comentar a interpretação de Furtado Coelho na peça A Honra de uma Família, encenada sem indicação de autoria, afirma:

"O Sr. Furtado Coelho, Paulo de Chennevières, pintou o caráter de que estava encarregado com expressão e verdade. Teve cenas de verdadeira expansão, no segundo ato sobretudo. O que se nota neste artista, e mais que em qualquer outro, é a naturalidade, o estudo mais completo da verdade artística. Ora, isto importa uma revolução; e eu estou sempre ao lado das reformas. Acabar de uma vez com essas modulações e posições estudadas que fazem do ator um manequim hirto e empenado é uma missão de verdadeiro sentimento da arte. A época é de reformas, e a arte caminha par a par com as sociedades" ( $C T$, p. 45$)$.

Furtado Coelho foi o principal intérprete do realismo teatral. Português, nascido em Lisboa em 1831, havia chegado ao Brasil em março de 1856, ligando-se logo ao Ginásio, onde foi ensaiador durante alguns meses. No ano seguinte estreou como ator no Rio seus desempenhos em peças de Alexandre Dumas Filho, Émile Augier, Octave Feuillet ou Théodore Barrière foi tão grande que em pouco tempo tornou-se o principal rival de João Caetano, até então sem ameaças à sua glória. Os críticos e o público encantaram-se com a gestualidade contida, a voz bem-modulada, a naturalidade e os gestos elegantes do ator talhado para os papéis centrais das comédias realistas. Machado fez muitos elogios aos desempenhos de Furtado Coelho, nos folhetins de O Espelho, embora não o tenha poupado de restrições, quando julgou necessário. Assim, considerando naturais algumas incorreções “em uma vocação que a prática não amadureceu ainda", pede ao ator que observe como às vezes avança demais a cabeça ou conserva as mãos fechadas, atitudes "que ofendem a elegância do palco" (CT, pp. 88-9). Nos anos que se seguiram, Furtado Coelho aperfeiçoou a sua interpretação realista. Machado o elogia numa das crônicas da série "Ao Acaso", em 1865, afirmando que no papel de Eugênio, protagonista do drama Cancros Sociais, de Maria Ribeiro, ele soube "reproduzir com as cores da verdade" os sentimentos diversos que agitam a alma do personagem. E mais: "É na alta comédia e no drama de sala que aquele artista tem feito a sua brilhante reputação; se alguma coisa faltasse para firmar-lha, bastaria para isso o seu último papel"s. Nessa época, Machado estreita a sua amizade com Furtado Coelho e torna-se seu colaborador. Traduz, para a companhia dramática dirigida pelo amigo, as peças Suplício de uma Mulher, de Émile de Girardin e Dumas Filho (1865); O Anjo da Meia-noite, de Théodore Barrière e E. Plouvier (1866); O Barbeiro de Sevilha, de Beaumarchais (1866); A Família Benoiton, de Victorien Sardou (1867); e Como Elas São Todas, de Alfred de Musset (1868).

Sobre o estilo de interpretação de Furtado Coelho, vale a pena ler um trecho de uma carta que o ator recebeu de um amigo de Machado, o escritor e jornalista Joaquim Serra, em 1863. Trata-se de um documento precioso para que compreendamos claramente como um intelectual da 
época via as diferenças entre os "acrobatismos" do ator romântico e a naturalidade do ator realista:

"Vi-te na cena, e sinto não poder exprimir as sensações que o teu talento em mim produziu.

A arte dramática moderna, passando pelo crisol da escola realista, apurou-se e chegou ao supremo grau de perfeição.

O furor da cólera, o êxtase do amor, tudo quanto a alma humana possui de terrível, doloroso e profundo, pode ser fielmente trazido para a cena sem os acrobatismos da escola romântica.

Tu és o mais aproveitado dos sectários da nova escola.

Triunfas porque és natural e verdadeiro; porque sente-se palpitar a fibra e bater a artéria quando pões em cena alguma paixão; porque estudas as dobras e refolhos do coração humano, sem essas terríveis contorções, que, tirando a elevação dos papéis, pode, quando muito, acreditar o artista como uma obra-prima de mecânica.

Triunfas, porque não concedes um gesto à arte vulgar; não dás arras e nem fazes concessões a essas popularidades parvas e balofas, que degradam a arte. Não sacrificas a verdade ao efeito e nem a harmonia e ritmo de palavra, ao trovejar da voz, que desnatura a verdade"

Furtado Coelho, como se vê, não gritava em cena e evitava qualquer tipo de exagero. Seus desempenhos, para os admiradores de João Caetano, eram defeituosos, porque por vezes falava até baixo demais e evitava o “jogo de fisionomia", isto é, não representava o tempo todo com o rosto voltado para a platéia, à qual inclusive dava as costas, à semelhança dos artistas franceses do Gymnase Dramatique de Paris. Mas foram esses procedimentos que o consagraram como artista responsável pela renovação da cena brasileira, naqueles anos de disputa acirrada entre os adeptos do Romantismo e do Realismo.

Nos folhetins de $O$ Espelho, a preferência de Machado pelo estilo de interpretação realista é visível também nos elogios a artistas provenientes do São Pedro deAlcântara, que precisaram fazer o aprendizado da naturalidade em cena. Não era fácil para os artistas formados na escola de João Caetano adaptar-se às exigências dos papéis das comédias realistas. Eis uma prova disso:

“O Sr. Heller, no papel de Chennevières, revelou muito talento que andava encoberto quando errava lá pelas constelações do romântico. Este moço tem se desenvolvido muito depois que se uniu ao Ginásio; foi a pedra de toque de uma vocação larga. No drama de domingo, sobretudo, teve momentos belos, cenas perfeitas.

Há talvez ainda uns laivos de uma educação artística viciosa; a fala ressente-se de uma gravidade própria do romantismo. Mas esse derradeiro crepúsculo de uma aurora mal despontada vai desmaiando: e o Sr. Heller tem-se mostrado um digno companheiro de seus novos colegas.

No terceiro e quarto ato tem cenas tão belas, tão bem desempenhadas; há tanto sentimento no dizer do papel de que se incumbiu, que o Sr. Heller conquistou um lugar de ora avante distinto na cena. Uma fisionomia móbil - é ainda um mérito que ele põe em execução com um resultado feliz. Não imitou, reproduziu a figura que lhe estava confiada" ( $C T$, pp. 43-4).

Esse tipo de comentário se repete nas páginas de $O$ Espelho, quando Machado comenta o pequeno progresso da atriz Teresa Martins, que antes se prejudicava pela "escola viciosa em que estava" ( $C T$, p. 149). Ou quando aponta a qualidade da interpretação de Joaquim Augusto no papel do octogenário Laroque, do Romance de um Moço Pobre, de Octave Feuillet. A seu ver, depois que se transferiu para o Ginásio, Joaquim Augusto "veio mostrar-nos a transfiguração de uma vocação erradia outrora em um clima que lhe não convinha, e que forçosamente lhe nulificava a aptidão e a inteligência". Considerava que um artista "consciencioso" como ele, "aperfeiçoado pelo estudo e pela observação, não podia viver na luz melancólica que um quadro envelhecido lhe podia dar; o romantismo
9 Joaquim Serra, "Carta a Furtado Coelho", in João Roberto Faria, déias Teatrais: o Século XIX no Brasil, São Paulo, Perspectiva/ Fapesp, 2001, pp. 555-6 
não se acordava com a sua fibra dramática; chamava-o uma outra escola, uma outra platéia" (CT, pp. 156-7).

Joaquim Augusto Ribeiro de Sousa era brasileiro, nascido no Rio de Janeiro em 1825, e iniciara a carreira muito jovem, na companhia dramática de João Caetano. Mas foi no Ginásio que se consagrou como intérprete, trabalhando ao lado de Furtado Coelho e da atriz portuguesa Gabriela da Cunha, em diversas peças realistas. Não era um galã, mas o que na época se denominava “centro dramático”. Quando Furtado Coelho se ausentou do Rio de Janeiro, nos primeiros anos da década de 1860 , ele tornou-se o principal artista do realismo teatral, rivalizando com João Caetano e assumindo inclusive as funções de ensaiador e empresário do Ginásio Dramático. Machado gostava de seu trabalho como intérprete e elogiou-o em várias ocasiões, chegando mesmo a afirmar que no papel do cavalheiro de Maubreuil, da peça $A$ Honra de uma Família, "tocou por vezes o sublime da arte" e no quarto ato "maravilhou a platéia" ( $C T$, p. 42). Quando o viu em cena, "com traços vivos e largos", no papel de um usurário da peça Os Homens de Mármore, do português Mendes Leal, afirmou: "É um desempenho notável e feliz em que há perfeito acordo de detalhes, em que maneiras, característico, palavras, olhar, movimento, se grupam para dar em resultado esse usurário frio como mármore, cínico como a avareza"10. Artista admirado pelos contemporâneos, mereceu elogios de vários críticos e intelectuais. Eis algumas linhas de Joaquim Manuel de Macedo sobre o seu estilo de interpretação: Teatros", in João Roberto Faria, Idéias Teatrais: o Século XIX no Brasil, op. cit., p. 508.

11 In João Roberto Faria, O Teatro Realista no Brasil: 1855-1865, São Paulo, Perspectiva/Edusp 1993, p. 119. Nesse livro, no capítulo "As Noites do Ginásio", o leitor pode colher várias informações biográficas e críticas sobre os principais artistas do Ginásio Dramático.

12 Machado de Assis, Crônicas, op. cit., $2 \div$ vol., p. 210

13 In João Roberto Faria, O Teatro Realista no Brasil: 1855-1865 op. cit., p. 126 ções, e tem assim o condão de sustentar a ilusão por modo tal, que a ilusão se afigura realidade""11.

Com as qualidades apontadas por Macedo, mais a boa pronúncia, o cuidado na projeção da voz, os gestos medidos, Joaquim Augusto, ao lado de Furtado Coelho, contribuiu de maneira notável para a afirmação do realismo teatral em nossos palcos.

Entre as atrizes do Ginásio, Machado admirava em primeiro lugar a portuguesa Gabriela da Cunha, radicada no Brasil desde mocinha. Tinha algum apreço por Maria Velluti e considerava Eugênia Câmara - a futura amante de Castro Alves - uma atriz limitada pelo estro cômico. Pouco escreveu sobre Adelaide Amaral, que não fazia parte do Ginásio em 1859, mas que havia se destacado nas temporadas de 1857 e 1858 como atriz que compreendera perfeitamente a noção de naturalidade - depois de ter trabalhado com João Caetano. Em 1861 ela teve o seu melhor ano no Ginásio, como intérprete de comédias realistas de sucesso, com destaque para Os Mineiros da Desgraça, de Quintino Bocaiúva, e $A$ História de uma Moça Rica, de Pinheiro Guimarães. Em 1864, Machado a elogiou no desempenho do principal papel feminino da peça Montjoye, de Octave Feuillet, que ele mesmo havia traduzido para o Ginásio. Quando o amante da personagem é trazido ferido para a cena, ela exprime a dor e a angústia com "um grito e um movimento fisionômico cheios de verdade" ${ }^{12}$. Segundo se lê no pequeno jornal Entreato, agradava na atriz, "a par de uma fiel compreensão dos caracteres que representava, a naturalidade com que os reproduzia, afastando-se dos grosseiros hábitos, dos vícios da velha escola de declamação que transforma os atores em pregoeiros de frases"13.

Gabriela da Cunha, nascida em 1821 também tinha passado pelo palco do São Pedro de Alcântara, mas foi no repertório do realismo teatral que se consagrou. Ninguém a igualou na interpretação das heroínas de Barrière ou Dumas Filho. E Machado jamais fez qualquer restrição ao seu trabalho de intérprete. Ao contrário, os elogios 
foram tantos que pelo menos um dos seus biógrafos enxergou uma paixão amorosa onde havia apenas amor à arte e interesse pelas coisas do teatro ${ }^{14}$. O que Machado admirava em Gabriela da Cunha era a sua capacidade de ser verdadeira em cena. A expressão dos sentimentos vinha sempre na medida certa, sem exageros, mas sem frieza. Esse equilíbrio deu-lhe nomeada logo nos primeiros anos do Ginásio, em 1855 e 1856, pois foi ela “a primeira que nos revelou os belos trabalhos do teatro moderno francês, e de modo a encher de orgulho a cena brasileira"15. Artista de alto nível, nem mesmo nas peças menores deixava de brilhar. Como protagonista do drama Valentina, encenado sem indicação de autoria, teve um "desempenho magistral": "A unção de sentimento, deu-a ela, à frase e ao gesto: e nas cenas capitais da peça, reproduz tanta verdade, que o espírito como que se incomoda; é doloroso demais" (CT, p. 110). Machado a viu em muitas peças e não poucas vezes deixou-se levar pelo entusiasmo. Eis como descreve a interpretação que a atriz deu ao papel central de A Dama das Camélias:

“Confesso, não me cansa nunca esse magnífico drama. Mas não me cansa com essa Margarida Gautier que a Sra. D. Gabriela nos sabe dar; frívola ao princípio, depois sentimental, depois apaixonada, resignada enfim no alto do seu amor, tendo percorrido a escala gradual desse sentimento lustral que a lava da culpa e lhe ergue uma coroa de flores em sua sepultura de tísica. Com essa Margarida pálida e arquejando do quarto ato, desvairada com a afronta de Armando, procurando colher e adivinhar as suas palavras, e curvando-se pouco a pouco à proporção que elas lhe caem dos lábios, até ao grito final, expressão sintética de um despedaçar interno de ilusões e de vida. Com essa Margarida do quinto ato, abatida e prostrada, que morre quando parecia voltar à vida, com o riso nos lábios e a mocidade na fronte" 16 .

Primeira atriz do Ginásio, Gabriela da Cunha foi, na nomenclatura da época, uma extraordinária "dama-galã", isto é, uma atriz com todos os requisitos necessários para interpretar as heroínas das comédias realistas. Voz e gestos sempre adequados, sabia comover sem exagerar, dando ao estilo realista de interpretação teatral a sua versão feminina mais bem-realizada, segundo os folhetinistas da época.

\section{IV}

Os textos críticos de Machado, escritos em 1859, não deixam dúvida quanto ao posicionamento estético que adotou. Preferia o Realismo ao Romantismo, a naturalidade dos artistas do Ginásio aos exageros dos que atuavam no São Pedro de Alcântara. Isso não impediu, como vimos, que reconhecesse o talento de João Caetano como intérprete de tragédias, dramas ou melodramas. Infelizmente escreveu pouco sobre os papéis desempenhados pelo grande ator, de modo que não pudemos extrair de seus textos descrições mais detalhadas, seja do estilo trágico, seja do estilo romântico de interpretação. O mesmo ocorre nas crônicas escritas entre 1860 e 1863 , anos em que o realismo teatral se consolida na cena brasileira.

É em 1864 que Machado acompanha com grande interesse a temporada de Emília das Neves, então a maior atriz de Portugal, que trazia para o Rio de Janeiro uma boa parte do seu repertório, quase todo formado por peças românticas. Como cronista do Diário do Rio de Janeiro, Machado assistiu a vários espetáculos e não economizou elogios ao estilo de interpretação de Emília das Neves, demonstrando que suas objeções ao Romantismo, em passado recente, dirigiamse mais aos exageros dos artistas no palco do São Pedro de Alcântara - viciados no melodrama - do que ao movimento literário e artístico propriamente dito ou a suas obras. Nessa altura já havia relativizado seu apoio ao realismo teatral e procurava julgar peças e espetáculos de acordo com critérios estéticos. Assim, mostra que o drama romântico em cena não o incomoda, desde que bem representado, obedecendo ao bom gosto
140 biógrafo é R. Magalhães Júnior, em: Vida e Obra de Machado de Assis, Rio de aneiro Civilização Brasileira INL-MEC, 1981, v. 1, pp. 115 27

15 Machado de Assis, "Comentários da Semana", in JeanMichel Massa, Dispersos de Machado de Assis, Rio de Janeiro, MEC/INL, 1965, p. 168

161 ldem, "Revista de Teatros", in João Roberto Faria, Idéias Teatrais: o Século XIX no Brasil, op. cit., p. 507 
e a determinados padrões artísticos. Por isso, logo depois do espetáculo de estréia de Emília das Neves, com o drama Joana a Doida, que já havia sido encenado por João Caetano e Ludovina Soares da Costa, Machado ressalta o "superior talento" da atriz e registra seu primeiro sucesso em nossos palcos:

"A peça escolhida pôde dar de algum modo a medida dos seus recursos e dos seus dotes. Joana é a expressão exaltada do amor, do amor que chora, vinga, pede e enlouquece; do amor que faz da rainha uma mulher, da mulher uma Nêmesis, da Nêmesis uma louca.

Representar cabalmente Joana era dar prova de uma alta capacidade artística. Emília das Neves conseguiu este resultado com que ganhou uma vitória esplêndida.

A gravidade do gesto, a eloqüência da fisionomia, a distinção do porte, uma natureza abundante casada a uma arte profunda-tudo isso se encontra na eminente artista. E se a estes dotes, juntar-se o de uma voz que sabe falar, gemer, odiar, comover, teremos reconhecido em Emília das Neves os seus talentos capitais e os seus altos recursos" ${ }^{\text {17 }}$.

Os termos empregados por Machado revelam uma interpretação distante daquela baseada na naturalidade em cena, em que o artista - para lembrar as palavras de Alencar - "vive" o papel que lhe foi atribuído como se fosse uma criatura real, flagrada no interior de uma casa do Rio de Janeiro. Os sentimentos e as emoções fortes da personagem Joana exigiam uma interpretação exuberante, vigorosa, que Emília das Neves conseguiu sem apelar para os exageros da interpretação melodramática, e sem abdicar da intensidade necessária.

Para Machado, a atriz dominava o seu ofício porque estudava os sentimentos das personagens que encarnava no palco. Sabia como exprimi-los, como sabia "realizar a difícil e rara aliança da arte e da natureza" 18 . Quer dizer, em papéis que exigiam a expressão de sentimentos fortes, não caía em exageros e não traía o ideal artístico. No drama A Mulher que Deita Cartas, de
Victor Séjour, interpretando a judia Geméia, que "procura com amor, com perseverança, com desespero, a filha das suas entranhas", Emília das Neves tinha em mãos um papel com defeitos, diz Machado, mas com interesse humano, qualidade que a atriz soube acentuar em sua interpretação:

"Em mais de uma cena subiu ao patético; teve gritos de leoa para as agonias supremas, teve lágrimas tocantes para as dores do coração; soube ser mãe e mulher.

Familiar aos grandes efeitos da cena, Emília das Neves emprega-os com a discrição necessária para não cair das alturas da natureza e da arte. Sombria ou radiante, irada ou terna, amorosa ou odienta, ela sabe que, em cada uma dessas fases do sentimento, a arte exige um toque ideal" 19 .

A impressão que temos, lendo essas palavras, é que a atriz não evitou o exagero nainterpretação. Mas Machado nos garante que nem mesmo ao representar o papel de louca no drama Madalena, escrito "na época mais fervente da escola romântica" ${ }^{20}$, Emília deixou de ser sublime. Em outra peça, A Louca de Toulon, venceu o desafio de enlouquecer em cena: "[...] essa passagem da razão para a demência, altamente difícil por correr o risco da exageração e da extravagância, fê-la Emília das Neves com uma arte suprema"21.

Ao comentar a encenação do drama Angelo, de Victor Hugo, Machado aproveita para expor seu ponto de vista sobre a degeneração do teatro romântico, causada por escritores sem talento: “A escola romântica, que partilha ainda hoje com a realista o domínio do teatro, só tem produzido monstros informes. Os gênios iniciadores conservaram-se na altura donde olhavam para baixo; os imitadores deixaram-se arrastar no chão da sua mediania"22. Victor Hugo é louvado pelo belo drama que escreveu e que nos coloca "diante da violência das paixões e da energia dos caracteres”. Emília das Neves ganha os elogios do cronista, porque abalou a alma do público com sua interpretação do papel de Tisbe, “em quem o amor, o ciúme, o ódio tomam proporções 
colossais". Para exprimir esses sentimentos, "gesto, voz, fisionomia, tudo fala, tudo se apaixona, tudo ama e odeia, naquela artista privilegiada" ${ }^{23}$.

Pode-se dizer que Machado, pela primeira vez, pôde apreciar o estilo de interpretação romântica em sua plenitude. Apesar do repertório desigual, de alguns dramas de pouco valor literário, Emília das Neves impressionou a platéia brasileira. Mostrouse atriz completa, de muito talento e certa versatilidade. Apresentou-se também em comédias e brilhou como protagonista de $A$ Dama das Camélias. Por fim, pôs em cena a tragédia Judite, de Giacometti, saindose bem como atriz trágica, na opinião de Machado. O sucesso que obteve no Rio de Janeiro pode ser avaliado pela descrição da sua despedida, feita por Sousa Bastos:

"Em seu benefício e despedida, representou ali, no teatro de S. Pedro de Alcântara, a Medéia. Foi uma noite de verdadeiro delírio. Teve de andar de camarote em camarote abraçando todas as senhoras, de quem se despedia. Mais de duas mil pessoas a acompanharam a casa com archotes e banda de música à frente, estendendo nas ruas os casacos para ela pisar. Ofereceram-lhe por essa ocasião um álbum, em que estava impressa a Dama das Camélias, coroas de ouro, prata e flores, inúmeras poesias, felicitações de todas as corporações, etc." 24 .

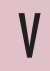

Quando apreciou a interpretação que Emília das Neves deu à protagonista da tragédia Judite, Machado não podia supor que, cinco anos depois, a experiência de ver uma atriz trágica em cena seria ainda mais completa. Antes de Emília, ele havia visto e apreciado João Caetano em Cinna, de Corneille, e possivelmente alguma tragédia com Ludovina Soares da Costa. Ou seja, Machado não podia avaliar o que era verdadeiramente o estilo de interpretação trágico. Isso mudou em 1869. Em junho desse ano, o Rio de Janeiro recebeu pela primeira vez uma artista dramática de nível internacional, a italiana Adelaide Ristori, considerada por muitos estudiosos do teatro a maior atriz trágica do século XIX. Para se ter uma idéia de seu prestígio, basta dizer que foram os franceses que a consagraram, em duas temporadas nas quais ela atuou em Paris, nos anos de 1855 e 1856 . Em seu livro de memórias e estudos, Ricordi e Studi Artistici, a atriz conta imodestamente que após o quarto ato da tragédia Mirra, de Alfieri, o público aplaudia com delírio a sua interpretação e os principais críticos e escritores teatrais franceses, comoAlexandre Dumas, Jules Janin, Legouvé, Scribe e Théophile Gauthier, estavam a seus pés. A prova de que o relato é verídico está no final do volume: as transcrições dos textos críticos atestam que Ristori foi posta acima da até então reverenciada Rachel, a grande atriz trágica que no auge do Romantismo havia reerguido a tragédia clássica na França.

Machado conhecia a fama de Adelaide Ristori pela leitura de jornais estrangeiros. Em carta a Quintino Bocaiúva, datada de outubro de 1866, revela ter lido no The Herald elogios entusiasmados à artista, então em tournée pelos Estados Unidos ${ }^{25}$. A oportunidade de vê-la em cena, no Rio de Janeiro, e escrever sobre suas interpretações não seria perdida. Com o pseudônimo de Platão, Machado assinou quatro artigos no Diário do Rio de Janeiro. Logo no primeiro reconheceu a grandeza da atriz, impressionado com a sua "figura imponente, escultural, rosto severo, voz sonora e vibrante"26. A interpretação do difícil papel de Medéia, da tragédia homônima de Ernest Legouvé, pareceu-lhe ter toques de gênio. À expressão dos sentimentos mais variados jamais falta verdade artística. Ristori evita o tom afetado, o convencionalismo, e, fiel à formação clássica, não confunde os seus sentimentos com os da personagem, ele observa. Nos momentos de desespero de Medéia, "vêse que ela conserva perfeita calma da sua consciência, princípio absoluto da arte, que nenhum talento esquece sem comprometer a sua personalidade". Além disso:

"Que inúmeras cordas tem a sua lira! A dor, a cólera, o desdém, o amor, a ironia,
23 Idem, ibidem, p. 311.

24 Sousa Bastos, Carteira do Artista, Lisboa, José Bastos editor, 1908, p. 287.

25 "Tu, a estas horas, terás tido o prazer de ouvir a Ristori, de que o Herald fala com tanto entusiasmo. Manda-me dizer a tua opinião" lcf. JeanMichel Massa, A Juventude de Machado de Assis, Rio de Janeiro, Civilização Brasileira, 1971, p. 574)

26 Machado de Assis, Adelaide Ristori: Folhetins, Rio de Janeiro, Academia Brasileira de Letras, 1955, p. 17 
o desespero, o ciúme, que longa escala de sentimentos nessa Medéia, e como Ristori os sabe exprimir com tão artística verdade! Tem para isso uma voz magnífica, vibrante, apaixonada. E que direi daquela fisionomia, que se presta, como a voz, a todas as modificações do sentimento? Ristori possui, como Garrick, a famosa gradação das paixões que o trágico inglês mostrava aos olhos pasmados de Mile. Clairon.

É o seu rosto o animado espelho da alma, dom supremo da arte teatral. Uma contração do rosto, uma expressão dos olhos vale às vezes um discurso inteiro, e ninguém melhor que Ristori possui esse dom de fazerse entender pelo gesto aos que não podem entendê-la pela língua"27.

Nessa bela página de crítica teatral, uma observação em particular mostra o quanto Machado era arguto e sabia "ler" um espetáculo. A certa altura do texto, descrevendo o trabalho de interpretação da atriz, ele afirma: "Cada gesto, cada passo, cada movimento revela uma intenção plástica e dá sempre uma atitude artística" ${ }^{28}$. A pertinência dessa afirmação pode ser buscada nas memórias de Ristori, na passagem em que ela comenta a entrada de Medéia em cena, acompanhada dos dois filhos:

"Trazia nos braços o pequeno Melanto, que apoiava sua cabeça loiraem meu ombro, euma parte do manto turquês, que devia em seguida cair novamente sobre as minhas costas, cobria metade de minha cabeça e escondia quase inteiramente a do menino. Eu havia colocado ooutro filho, Licaonte, do meu lado esquerdo; ele se apoiava em mim demonstrando enorme fadiga. No alto da montanha, eu parava um instante, como que enfraquecida. Observo

27 Idem, ibidem, p. 18

28 Idem, ibidem, p. 19

29 Adelaide Ristori, Ricordi e Studi Arristici, 2ed., Torino, L. Roux e C. 1888, p. 239

30 Idem, ibidem, p. 102

31 Cf. Alessandra Vannucci (org.) Uma Amizade Revelada: Correspondência entreolmperador Dom Pedrolle Adelaide Ristori a Maior Atriz de seu Tempo, Rio de Janeiro, Ediçōes Biblioteca Nacional, 2004 que essa postura, como muitas outras, eu havia adotado com base no estudo dos admiráveis grupos de Níobe, que se encontram na famosa Galeria dos Uffizi de Florença, na sala dita de Níobe"29.

Como se vê, Machado acertou em cheio ao perceber a "intenção plástica" nos gestos da intérprete. Ristori conta que essa aparição, em Paris, provocou enorme

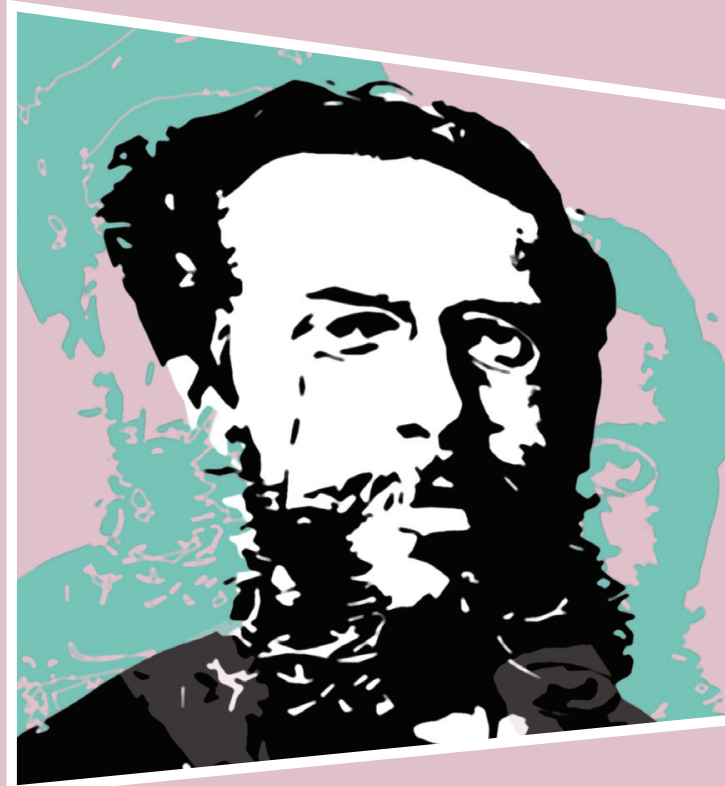

aplauso. E que ficou surpresa quando, no Rio de Janeiro, ao entrar assim em cena, foi recebida por uma acolhida glacial. Era sua estréia. E ao aparecer no alto da montanha, agrupada com os filhos, não ouviu nenhum aplauso ou manifestação de agrado. Ponderou que talvez a platéia estivesse intimidada diante dela ou da presença de D. Pedro II. Mas isso não durou mais do que um curto instante, conforme sua descrição do que se seguiu:

“Subitamente, ao primeiro efeito cênico, o entusiasmo dissipou a frieza! Foi quando Medéia, com palavras de desolação, dilacerada pelo lamento dos filhos pedindo pão, exclama: 'Não poder esvaziar as minhas veias / Até a última gota'. E completa: 'tomai/ Alimentai-vos, bebei o meu sangue!'. Esta invocação, saída impetuosamente dos meus lábios, do meu coração, provocou um frêmito que teve por resultado uma daquelas explosões de aplausos que são o batismo dos grandes sucessos" ${ }^{30}$.

Não duvidemos do relato de Ristori. Seu triunfo foi verdadeiramente imenso: ela foi elogiada por todos os folhetinistas, recebeu homenagens, presentes valiosos de admiradores e tornou-se amiga de D. Pedro II, com quem trocou cartas por mais de vinte $\operatorname{anos}^{31}$. Machado, nos outros três artigos que escreveu, não diminuiu o tom elogioso. Ao contrário, colocando-se como um crítico desarmado diante da intérprete genial, descreveu com entusiasmo incomum 
os momentos sublimes que presenciou como espectador das seguintes peças: Judite $e$ Isabel de Inglaterra, de Paolo Giacometti; Pia de Tolomei, de Carlo Marenco; Maria Stuart, de Schiller; Fedra, de Racine; Sóror Teresa, de Luigi Camoletti; Mirra, de Vittorio Alfieri; e A Estalajadeira, de Goldoni.

Para Machado, Ristori foi perfeita em todos os papéis. A seu ver, porque ela os estudava profundamente, jamais se contentando em subir ao palco apenas com o talento e a inspiração. Como atriz trágica, era inigualável. Seu estilo devia ser considerado um modelo para atores trágicos, mas não para ser copiado e sim estudado:

"Não haverá na arte teatral aquilo que existe na arte de escrever e na arte de pintar, o estilo? O estilo é a fisionomia do pensamento, a personalidade do artista e do escritor; tem-no o pintor, o poeta, o músico; não o terá o artista dramático? Mas se é difícil ao artista formá-lo, não menos difícil é à crítica defini-lo. Que os competentes venham explicá-lo melhor do que eu; basta-me dizer que ouvindo e vendo Ristori sinto que se há estilo verdadeiramente modelo para trágicos é o dela, e que, sem copiá-la, o que seria funesto, podem estudar-se com ela as leis e as regras do estilo teatral" 32 .

Chama a atenção no conjunto dos escritos a ênfase que Machado dá ao caráter universal dos sentimentos humanos presentes nas tragédias representadas por Ristori. A seu ver, essa forma dramática, “para ser interpretada, exige a capacidade máxima do gênio humano"33. Impressionado com o trabalho da atriz, o escritor maravilha-se diante da representação de Fedra, dedicando quase todo o artigo não à análise da tragédia de Racine, mas ao desempenho de Ristori, em que se sobressai o modo como ela uniu "os delírios da paixão e os recursos da plástica, o duplo ideal da beleza íntima e exterior" ${ }^{34}$. Cenas como a confidência a Enone, a confissão a Hipólito ou a explosão de ciúme da personagem são ressaltadas como estudos perfeitos dos sentimentos. Sua conclusão não poderia ser outra: "Não, jamais a paixão encontrou em cena maior intérprete do que esta; nem creio que Fedra fosse nunca reproduzida como na memorável noite de 15, que ficará sendo, para todos os que amam a arte e o belo, a mais elevada recordação que é possível conservar do teatro"35.

Como se vê, o estilo elevado de interpretação da tragédia concretizou-se diante dos olhos de Machado na figura imponente de Ristori. Para o escritor, foi uma experiência estética única, na qual o teatro mostrou-se como uma arte em que também se atinge o sublime.

\section{VI}

Dois anos depois de ver Ristori em cena e escrever sobre seus desempenhos, Machado pôde apreciar mais um artista de fama internacional. Em maio de 1871, Ernesto Rossi, que se notabilizara em toda a Europa como intérprete shakespeariano, estréia no Rio de Janeiro com o drama Kean, de Alexandre Dumas. E logo em seguida põe em cena Hamlet, Otelo, Romeu e Julieta e Macbeth. Machado ficou simplesmente encantado com o trabalho do ator - algumas cenas de Macbeth "são páginas de arte que se não apagam mais da memória"36, afirmou num pequeno artigo publicado na Semana Ilustrada, em 25 de junho. Mas infelizmente não entrou em detalhes sobre o estilo de interpretação do famoso ator e escreveu apenas mais um artigo, centrado na representação da peça Luís XI, de Casimir Delavigne. Chamou Rossi de "ilustre trágico" e ressaltou a versatilidade do ator e de seu repertório:

"Não tem clima seu: pertencem-lhe todos os climas da terra. Estende as mãos a Shakespeare e a Corneille, a Alfieri e Lord Byron: não esquece Delavigne, nem Garrett, nem V. Hugo, nem os dois Dumas. Ajustam-se-lhe no corpo todas as vestiduras. É na mesma noite Hamlet e Kean. Fala todas as línguas: o amor, o ciúme, o remorso, a dúvida, a ambição. Não tem idade; é hoje Romeu, amanhã Luís XI"37.

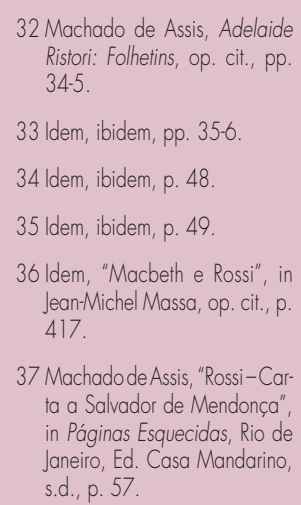


Importante no texto é o entusiasmo com que Machado se refere às peças de Shakespeare. Parecia-lhe, antes de assistir aos espetáculos, que bastava sua imaginação de leitor para perceber a grandeza e a beleza da obra do grande poeta inglês. Afinal, há nela tanta "vitalidade própria" que se afigura desnecessário o "prestígio do tablado". Rossi, encarnando os heróis shakespearianos, fê-lo mudar de opinião: “A vida que a esses caracteres imortais deu a nossa imaginação, sentimo-la em cena quando o gênio prestigioso do Rossi os interpreta e traduz, não só com alma, mas com inteligência criadora" 38 . E mais: a grandeza de Rossi, embora se tenha manifestado em todos os papéis que desempenhou, impressionou-o quando percebeu haver entre Shakespeare e o ator "uma afinidade intelectual, tão exclusiva e absoluta, que o ator nunca seria maior na intimidade de outro poeta, e que era esse a sua musa por excelência, e as suas obras a atmosfera mais apropriada ao seu gênio"39.

Machado confessa que considera Hamlet a peça mais profunda de Shakespeare e que vê-la em cena foi a realização de um sonho que considerava difícil de concretizar. A interpretação de Rossi, "naquele tipo eterno de irresolução e de dúvida" ${ }^{40}$, ficará gravada em sua mente para sempre. Se Ristori o havia impressionado tanto, dois anos

38 Idem, ibidem, p. 60.

39 ldem, ibidem, p. 57

401 ldem, ibidem, p. 61

41 ldem, ibidem, pp. 61-2

42 Idem, ibidem, pp. 60-1.

43 Dennis Kennedey (ed.), The Oxford Encyclopedia of Theatre and Performance, New York, The Oxford University Press, 2003, p. 1.157. Na sequêencia da citação, o estilo de interpretação de Rossi é contraposto ao de Tommaso Salvini, classificado como "clássico", por ser "mais estudado". Trata-se de questão controverso pois os críticos de língua inglesa do século XIX definiam Rossi e Salvini como intérpretes realistas. Sobre o assunto, pode-seler o belo livro de Marvin Carlson. The Italian Shakespearians: Performances by Ristori, Salvini, and Rossi in England and América (Washington, Folger Books, 1985. antes, como atriz trágica, eis como avalia as diferenças entre ela e Rossi: “[...] se o gênio de ambos é igualmente profundo, o de Rossi me parece mais vasto. Alguns dirão, talvez que, conquanto não haja para nenhum deles fronteiras de escola, a Ristori parecia amar especialmente a arte clássica, ao passo que o Rossi tem particular afeto à arte romântica"41.

Muito provavelmente as peças de Shakespeare fizeram a diferença. Afinal, a platéia brasileira, antes de 1871 , jamais havia visto uma delas em cena. Nopassado, João Caetano havia representado apenas as adaptações do escritor neoclássico francês François Ducis. Ao interpretar os papéis shakespearianos, Rossi impressionou a platéia brasileira como ator que "sabe traduzir a paixão de Romeu, os furores de Otelo, as angústias do Cid, os remorsos do Macbeth, que conhece em suma toda a escala da alma humana" ${ }^{42}$.

Em outras palavras, as interpretações de Rossi foram marcantes pela intensidade com que exprimiu os sentimentos dos personagens que encarnou. Machado as aproxima do estilo romântico, opondo-as às de Ristori, certamente porque se caracterizavam por mais vigor físico, mais expressividade facial e uso da voz com ênfase em contrastes agudos. De pequena estatura, mas robusto, Rossi "tinha uma face flexível, um corpo capaz de movimentos elásticos e gestos expressivos, e uma voz que alternava volume e tom com facilidade. A natureza tempestuosa e imprevisível de suas paixões tornou-o merecedor do título de ator romântico"43

Rossi foi o último grande artista teatral sobre o qual Machado escreveu. É claro que deve ter assistido às representações de peças de Shakespeare em setembro e outubro de 1871, quando o Rio de Janeiro recebeu outro grande artista italiano, Tommaso Salvini, rival de Rossi como intérprete shakespeariano. Mas não há notícia de que tenha se manifestado na imprensa. Já as poucas linhas que deixou sobre Eleonora Duse ou Sarah Bernhardt - as duas grandes divas do final do século XIX, que aqui estiveram mais de uma vez - não tratam de seus estilos de interpretação. $O$ fato é que o envolvimento de Machado com o teatro diminuiu bastante a partir da década de 1870, por uma série de razões, entre elas o casamento com Carolina, em 1869, e a dedicação aos contos e romances que formarão a porção principal da sua obra. De qualquer modo, o que pudemos observar nas páginas precedentes é que entre os 20 e 30 anos o teatro foi para Machado uma atividade importante. Além de ter escrito comédias e traduzido várias peças, foi censor do Conservatório Dramático e, como crítico e cronista, deixou um testemunho importante para a compreensão da história do teatro brasileiro num período muito rico em termos dramatúrgicos e cênicos. No recorte aqui feito, pudemos acompanhar a sensibilidade com que assistiu aos espetáculos e o rigor crítico com que julgou os artistas que viu em cena. 